\title{
The Relationship between Managerial Skills and Teaching Effectiveness of Elementary School Teachers
}

\author{
Mercedita H. Silva
}

\begin{abstract}
This study aimed to find out any significant relationship between the managerial skills and teaching effectiveness of the selected elementary teachers. Using a descriptive method of research, a total of 62 public elementary teachers from eleven (11) elementary schools in Candelaria West District in the Philippines during the academic year 2018-2019 were chosen as study participants. An expert-validate questionnaire in checklist form was the main tool for data collection. The perceived managerial skills of the teachers were manifested through their technical, conceptual and human skills. Meanwhile, the level of the teaching effectiveness is always effective in terms of management of students' behavior and assessment of students' learning and effective in organization of instruction and adjustment of learning. Results further revealed that there was significant relationship in managerial skills and teaching effectiveness in terms of management of students' behavior, organization of instruction, assessment of students' learning and adjustment of learning. The managerial technical skill was significantly related to teaching effectiveness. There is perceived necessity to develop further the managerial skills of the teachers. Administrator may provide programs and activities for improvement and application of teachers' managerial skills.
\end{abstract}

Keywords:

managerial skills, teaching effectiveness, classroom teacher, teaching framework

Suggested Citation: Silva, M.H. (2021). The Relationship between the Managerial Skills and Teaching Effectiveness of Elementary School Teachers. International Journal of Educational Management and Development Studies, Volume 2, Issue 2, pp. 1 - 19.

About the author:

Elementary School Teacher. Masin Norte Elementary School, Philippines. 


\section{Introduction}

The learning outcome depends largely on the teacher as the key factor in any teaching-learning situation. Improved learning outcome calls for the effective performance of a teacher, which is anchored on their teaching effectiveness. It is said that the effectiveness of teacher's performance contributed much to the student achievement. Their role requires more than the constructs of the classroom instructions. They need to assess the students where they are at, help them to construct knowledge, and further their understanding of the world around them, and maximize their potential learning.

It is true that teachers are important leaders of educational system. However, there is a growing concern in the public school system on the not-so-good performance of some teachers. Numerous studies and surveys have been conducted to initiate result and solve this problem. In response to this issue, schools in the Philippines conduct nationwide in-service program, and other seminars to enhance teachers' abilities. Administrators from district, division or regional offices conduct Field Technical Assistance (FTA) to observe the set standards for school performance, create assessments aligned with standards to measure performance, identify the lowest performing schools and make data on school performance for them to use for further improvements.

Pursuant to Division Memorandum No. 184 series of 2017 entitled 'School Based Management (SBM) Level of Practice', the schools of Candelaria West District including Masalukot III Elementary Schools responded to the artifacts of SBM principles such as leadership and governance, curriculum and learning, accountability and improvement, and management of resources. These artifacts serve as evidence for further improvement of teachers in addressing and creating a favorable learning institution to study effectively towards the achievement of the Department of Education (DepEd) mission.

Juan and Lasaten (2016) note effectiveness in teaching as the groundwork for progress and development in an increasingly diverse, complex, and globalized society. For this, teachers need to possess necessary skills to be effective in teaching. Fisher (2017) looks at teachers as managers that need the proper tools to manage. For example, globalization presses teachers to possess the necessary $21^{\text {st }}$ century skills so they can continually challenge the classrooms to be responsive. With this, as the classrooms become globalized, critical 
elements of 21 st century education have to be integrated to the teaching-learning process in order to adequately prepare learners for their expected roles in society. As effective management evolves, teachers need to upgrade their management practices as well.

Managerial skills are set of qualities and attributes in the personality of the managers that enable them to effectively manage the entire organization. These skills can contribute to the development of the team, each individual and other personnel in the institution. As applied to teaching, it is how teachers deal with students on the activities, perform administrative functions and act as a team with the other employees. These skills develop an organize programs and policies (Abila, 2014).

Believing teachers as managers, it is assumed that their ability to manage their work can lead to effective teaching. Thus, this study assessed the managerial skills and teaching effectiveness of the elementary public teachers to determine any significant relationship.

HO1: There is no significant relationship between the managerial skills and the teaching effectiveness of the public elementary school teachers.

\section{Literature review}

\subsection{Managerial Skills}

According to Magbojos (2012), good leadership can make academic work a more enjoyable and more productive experience for everyone. The managerial abilities are a complete understanding of the needs and objectives of the institutions. There are essential elements to effective management. For instance, Ranade (2009) mentioned that the essential elements required by teams to work efficiently include a common identity or goal, structure, and interdependence. These fundamental elements form the common basis and goals that will help members bond and develop trust, which establish team interdependency. This sense of unity can be achieved by emphasizing team-training activities for increasing interpersonal skills within culturally diverse teams. Team building develops the communication of one another to establish technique to contribute ones attitude to achieve the goal.

In terms of individual skills, teachers are expected to possess various sets of skills to help them carry on with their duties as teachers and managers. Javier (2016) suggests that technical skill, understanding of, and proficiency in, a specific kind of activity, particularly 
involving methods, process, procedures or techniques, is necessary for the teachers to possess. It involves special knowledge, analytical ability within that specialty and facility in the use of tools and techniques of the specific discipline. Locke (2010) considered technical skill as the ability to use knowledge, methods, and techniques of a specific discipline. Teachers in school are examples of people with technical skills as they are recognized as experts in their discipline and are presumed to have the ability to supervise other. School head has usually developed some expertise in a discipline or field of study. To successfully run an academic department, the chairperson must know how to teach the subject, how to organize the group, how to acquire resources, and how to evaluate performance. This also encompasses human skill, which involves the ability to understand, create motivation, and work with employees.

According to Robbins and Coulter (2009), for teachers monitoring and evaluation of students' performance, tasks and structural arrangements must be in place to ensure that goals are being met and that work is being done as it should be. This requires strategy, which according to Gumz (2017) provides a light at the end of the tunnel. For example, the teachers' project management develops teachers' ability to develop strategies. It is the direction of the team in aiming the success. In doing the project, each member search for the strategy to be used in the challenges to prove that the project can lead for the organization improvement.

In order to formulate strategies, teachers also must know how to conceptualize. For Vishwanath (2012), conceptual skill is the ability to visualize the organization as a whole. It includes analytical, creative and initiative skills, understanding the complexities of the overall organization, his ability to think in abstract, analyze work situation and his creature and innovative ability to access the environment. It is necessary to understand how the different components are related to each other and the institution as a whole. Patrinos (2010) believes that teachers need to further develop their conceptual skills in order to think strategically and take a broad long-term view. This will enable teachers to see what goes on their work environment and help them to react appropriately and reflectively to situations as they arise. They must consider environmental forces, resource flows, staff and administrative talent, board of education policies, reform mandates, parent complaints, and organizational 
change as significant inputs into the internal environment of the learning environment. People with conceptual skills must be very creative (Doyle, 2016).

As teachers enter the $21^{\text {st }}$ century, they need to possess Information Communication Technology (ICT) proficiency. There is a growing demand on the educational institutions to integrate ICT in teaching the skills and knowledge students need for the 21 st century. This restructuring process requires effective integration of technologies into the existing environment in order to enhance professional output in the school (Buabeng \& Mbati, 2014).

The main role of the teacher is to manage the classroom. According to Barberos (2019), they should mind the chief component of interest in the classroom. As such, teachers need to vary teaching styles and techniques so as not to cause boredom to the students in the classroom. It is valuable to develop human skills to connect with students from all walks of life. This skill depends on the teacher's ability to think in the abstract (Javier, 2016). For this, the teachers have the sense that they contribute to their communication and be more productive and effective in the students learn more in their instruction (Visiliko, 2012). If they have human skills, they will be able to manage every change within the organization. Managing the change has an impact on the characteristics of teachers (Maughan, 2012).

\subsection{Teaching Effectiveness}

According to Bell (2011), teacher's effectiveness in schools greatly depends on effective practice for pupil learning in its own specific context. For this, schools are obligatory to practice a multi-disciplinary team approach involving of the learner's parents and school stakeholders such as teacher, school principal, guidance and other workers in the institution (Laylo, 2018). The teachers must integrate all these aspects for effecting teaching.

Highly successful teachers are frequently called instructional leaders (Glorioso, 2016). As leaders, they must have a deep understanding of teaching and learning, including new techniques and strategies in teaching that emphasize problem solving and pupils construction of knowledge. Good instructional leaders have a strong commitment to success for all pupils, and are especially committed to improve instruction for groups of pupils who are learning strategies that fit the needs of the students. For this, teachers must design an effective framework for teaching (Libit, 2016). Although they are not the only possible 
description of practice, these responsibilities seek to define what teachers should know and be able to do in the exercise of their profession.

An effective teacher brings about intended learning outcomes (Ryan, 2013). The goal of these activities is to ensure that all students learn what is expected of them. To do this, a teacher must master a variety of perspectives and strategies in teaching and flexible in their application (Carpo, 2014). According to Refugido (2015), teaching strategies are the techniques or approach that a teacher use for a certain topic or lesson determined by the teacher to be the best method in teaching based on different factors such as method, size class, kinds of students and availability of materials. However, teacher should also personalize the learning for their students (O' Neill, 2009). They used techniques that have each student working on tasks that engage and challenge them to achieve their best. For example, the learning activities are planned to suit the individual needs, interests and abilities of an individual student (Salandanan, 2012). They could use technology in developing the strategy (Agbatogun, 2012) or integrate technology in the teaching process (Arnseth \& Hatlevik, 2012) for students to enjoy learning.

Another key role of the teacher is preparation of assessments. Assessment allows the teachers to keep a record of their observations of student's works will support conclusions they draw which they will report to the parents (Lucas, 2017). Through a variety of measures, students are assessed to determine whether or not they are achieving the learning outcomes (Esllera, 2016; Stecher, 2010; Khandaghi \& Farasat, 2011; Morales, 2016). Teachers can compile them into a portfolio (William \& Thompson, 2008) which reflects student's development as well as the area where they have the weaknesses, which need to evaluate and give certain enrichment activities.

Managing the classroom is another mark of an affective teaching. $\mathrm{Vu}$ (2009) considers managing students' behavior and classroom social environment an important role in students' development. Student experiences within the classroom help to develop their behavioral, social, and academic skills. For this, Durrant (2010) suggests that an effective discipline must be constructive and positive. The same applies to correcting student mistakes. The process of receiving school correction may unintentionally influence how the students attach to the school and school agents, aspire to achieve academically, and perceive school rules and safety (Scaggs, 2009). 


\section{Methodology}

The descriptive method of research was employed in the study. This type of research determines the present conditions focusing on individual motivational factors, management skills and teaching effectiveness of public elementary classroom teachers. In order to produce data about the variables under the study, self-made questionnaire was used.

This investigation was undertaken in eleven elementary schools in Candelaria West District for School Year 2018-2019, namely: Buenavista East, Buenavista West, Bukal Norte, Bukal Sur, Candelaria Elementary School 1\&2, Candelaria Elementary School-Main, Masalukot I, Masalukot II, Masalukot III, Masin and Mayapyap. Complete enumeration technique was used in selecting the teacher-respondents so that all teachers in each school has the equal chance to be the sample. There were a total of 162 teacher-respondents of the study.

To facilitate the gathering of information the researcher used the descriptive survey questionnaire. The questionnaire was divided into two parts as follows: Managerial Skills (technical, conceptual and human) and Teaching effectiveness (student management, organization of instruction, assessment of student learning and adjustment of leaning). These indicators in the form of 4-scale Likert style were validated by the experts including ten (10) external validators, one (1) English teacher, two (2) Principal, five (5) Master Teacher, one (1) Teacher III, and one (1) Master in educational management graduate. To test the reliability, the instrument was subjected to test-retest method. Ten (10) teachers answered the questionnaire and were requested to note down any difficulties in answering. After two (2) weeks, the same instrument was given to the same ten respondents to check the reliability.

The author personally conducted the data gathering through personal visits to the schools where the respondents are working. The assistance of the school administrators was solicited to ensure success in the retrieval of the questionnaires.

Several statistics were utilized such as weighted mean, standard deviation, Pearson Product- Moment Correlation Coefficient at .05 level of confidence. 


\section{Findings and Discussion}

\begin{tabular}{|c|c|c|c|}
\hline Indicators & Mean & SD & Interpretation \\
\hline Technical & 3.40 & 0.56 & $\mathrm{P}$ \\
\hline Conceptual & 3.45 & 0.54 & $P$ \\
\hline Human & 3.43 & 0.55 & $\mathrm{P}$ \\
\hline Over All & 3.42 & 0.56 & $\mathbf{P}$ \\
\hline
\end{tabular}

\section{Table 1}

\section{Perceived Managerial Skills of Elementary School Teachers}

Legend: 3.51 - 4.00 Always Practiced (AP);2.51 - 3.50 Practiced (P); 1.51 - 2.50 Less Practiced (LP); 1.00 - 1.50 Not Practiced (NP)

Reflected in table 1 are the perceived managerial skills of the elementary teachers with the overall mean of 3.42 and standard deviation of 0.56 . It implies that the elementary teachers practice all the indicators of managerial skills. Specifically, the conceptual skills are the most practiced which implies that elementary teachers develop their concepts in dealing the overall challenge of the institution as whole.

In terms of technical skills, the teachers assessed their task management (WAM=3.41; $\mathrm{SD}=0.45$ ), project implementation (WAM=3.42; $\mathrm{SD}=0.55$ ) and ICT skills (WAM=3.4; $\mathrm{SD}=$ 0.58 ). The results imply that the teachers practiced all these indicators. The manifestations of the task management include giving task for student to develop responsibility and taking tasks that gives the opportunity to play the role of designate learners to be a cleaner of the day. Meanwhile, as to project implementation, they keep the program on track and complete them on time. The indicators of ICT skills for the teachers include the use of technology in many aspect, update technological skills and innovate and support technology resources. The results of the study affirm the discussions and studies of Gumz (2017), Grady (2011), Buabeng and Mbati (2014) and Robbins and Coulter (2009).

In terms of conceptual skills, the indicators assessed were strategic planning (WAM=3.53; $\mathrm{SD}=0.53$ ), problem solving (WAM=3.43; $\mathrm{SD}=0.54$ ) and change management (WAM=3.41; $\mathrm{SD}=0.56$ ). Teachers practice strategic planning through support to the school mission, vision and values and understanding how learning best occurs as a role of teachers as facilitator. Moreover, the practices of problem solving involve seeing what goes on in the 
working environment and reflecting on appropriate solutions as they arise. The manifestations of change management emanate from adaptation to changes in their current environment. These are consistent with the results of the studies of Patrinos (2010), Doyle (2016) and Atienza (2016).

In terms of human skills, the indicators assessed were communication (WAM=3.45; $\mathrm{SD}=0.56)$ and team building (WAM=3.42; $\mathrm{SD}=0.56$ ). The manifestations of communications include matching words to actions, developing various lines of communications and advocating for clear and consistent communication while practices of team building include advocating all teachers play a role, sharing expertise and sharing roles among team members. These manifestations are consistent with the discussions of Herrera (2010) and Ranade (2009).

\begin{tabular}{lccc}
\hline \multicolumn{1}{c}{ Indicators } & Mean & SD & Interpretation \\
\hline Management of Students' Behavior & 3.60 & 0.53 & AE \\
Organization of Instruction & 3.52 & 0.53 & $\mathrm{E}$ \\
Assessment of Students' Learning & 3.56 & 0.52 & $\mathrm{AE}$ \\
Adjustment of Learning & 3.43 & 0.56 & $\mathrm{E}$ \\
\hline \multicolumn{1}{c}{ Over All } & 3.53 & 0.53 & $\mathrm{AE}$ \\
\hline
\end{tabular}

\section{Table 2}

\section{Perceived Teaching Effectiveness of the Elementary School Teachers}

Legend: 3.51 - 4.00 Always Effective (AE); 1.51 - 2.50 Less Effective (LE); 2.51 - 3.50 Effective (E); 1 - 1.50 Not Effective $(N E)$

Table 2 shows the overall assessment of the teaching effectiveness with an over all mean of 3.53 and standard deviation of 0.53 . The data show that they are effective teachers in terms of management of students' behavior (WAM=3.60; $\mathrm{SD}=0.53$ ), organization of instruction (WAM=3.52; $\mathrm{SD}=0.53$ ), assessment of student learning (WAM=3.56; $\mathrm{SD}=0.52$ ) and adjustment of learning (WAM=3.43; $\mathrm{SD}=0.56$ ).

As to management of students' behavior, the indicators were discipline (WAM=3.60; $\mathrm{SD}=0.53$ ) and rules $(\mathrm{WAM}=3.59 ; \mathrm{SD}=0.53)$. These are manifested by solving the problems of students, addressing discipline to develop pupils' attitude, following school rules, posting rules before the first day of school and communicating to students and parents verbally and 
in written form the rules and regulations. These are congruent to the findings of Pineda (2014) on classroom discipline.

In terms of organization of instruction, it was assessed through strategy (WAM=3.54; $\mathrm{SD}=0.51)$ and methods $(\mathrm{WAM}=3.50 ; \mathrm{SD}=0.54)$. These are practiced in terms of developing range of students' abilities and aptitudes, using techniques that engage and challenge the pupils, providing opportunities for the different needs of the students, adapting instruction to meet students' needs and integrating the learning objectives in the curriculum. These are consistent with Glorioso (2016) on teaching strategies, Salandanan (2012) on teaching activities and Libit (2016) on differentiated instruction.

In terms of the assessment of students' learning, it was assessed through portfolio (WAM=3.56; $\mathrm{SD}=0.52$ ) and performance task (WAM=3.56; $\mathrm{SD}=0.52$ ). The manifestation of these indicators include collecting various pieces of students' work, looking for students' works that exemplify the criteria, engaging students to perform situations that are meaningful and age appropriate and rating the students work with their collaborative effort. These are consistent with the study of Esllera (2016) and Stecher (2010) on assessment of student's academic achievement other areas.

As to adjustment of learning, the indicators were technology (WAM=3.45; SD=0.58) and research (WAM=3.44; $\mathrm{SD}=0.55)$. These were manifested in the utilization of learning technologies in teaching, introduction of different aspects of innovation in the teaching and learning process, promotion of better classroom pedagogy and parental involvement and introduction of different aspects of teaching and learning process. These are related to the suggestions of Arnseth \& Hatlevik (2012) on the use of ICT in teaching and Morales (2016) on the importance of action research.

\section{Table 3}

Correlation between the Managerial Technical Skills and Teaching Effectiveness

\begin{tabular}{|c|c|c|c|c|c|c|c|c|}
\hline \multirow[t]{2}{*}{ Technical } & \multicolumn{2}{|c|}{$\begin{array}{c}\text { Management of } \\
\text { Students' } \\
\text { Behavior }\end{array}$} & \multicolumn{2}{|c|}{$\begin{array}{l}\text { Organization of } \\
\text { Instruction }\end{array}$} & \multicolumn{2}{|c|}{$\begin{array}{c}\text { Assessment of } \\
\text { Students' Learning }\end{array}$} & \multicolumn{2}{|c|}{ Adjustment of Learning } \\
\hline & Discipline & Rules & Strategy & Method & Portfolio & $\begin{array}{l}\text { Performance } \\
\text { Task }\end{array}$ & Technology & Research \\
\hline $\begin{array}{l}\text { Task } \\
\text { Management }\end{array}$ & $.46 * *$ & $.63 * *$ & $.36 * *$ & $.35 * *$ & $.57 * *$ & $.50 * *$ & $.42 * *$ & $.38 * *$ \\
\hline $\begin{array}{l}\text { Project } \\
\text { Implementation }\end{array}$ & $.46 * *$ & $.57 * *$ & $.31 * *$ & $.39 * *$ & $.47 * *$ & $39 * *$ & $.27 * *$ & $.27 * *$ \\
\hline ICT Skills & $.29 * *$ & $.51 * *$ & $.26 * *$ & $.32 * *$ & $.46 * *$ & $.38 * *$ & $.48 * *$ & $.36 * *$ \\
\hline
\end{tabular}


Legend: $\pm .01-2.0$ Negligible Correlation; $\pm .21-.40$ Low Correlation; $\pm .41-.70$ Substantial Marked Relations; $\pm .71-.90$ High Correlation; $\pm .91-.99$ Very High Correlation; $r=.1$ Perfect Correlation; $N=162, r$ value is significant at ${ }^{* *} p<0.01$

The table 3 displays the correlation between the managerial technical skills and the teaching effectiveness of the public elementary classroom teachers. The result shows that majority of the managerial technical skills indicators have substantial marked relations or low correlation to the teaching effectiveness. The positive correlation implies that the managerial technical skills positively influences the teaching effectives. As such, as the technical skills improve, the teaching effectiveness also improves.

The highest correlation is denoted by the relationship between project implementation and rules (0.57) and task management and portfolio (0.57). The lowest correlation is between the ICT skills and strategy (0.26). It denotes classroom teachers' technical skills influence how they shape the behavior of learners as they implement rules to maintain the orderliness of the learning environment. Moreover, they give task, implement project and used ICT skills to organize the strategies and methods in providing varied activities for students development.

\section{Table 4}

Correlation between the Managerial Conceptual Skills and Teaching Effectiveness

\begin{tabular}{|c|c|c|c|c|c|c|c|c|}
\hline \multirow{2}{*}{ Conceptual } & \multicolumn{2}{|c|}{$\begin{array}{c}\text { Management of Students' } \\
\text { Behavior }\end{array}$} & \multicolumn{2}{|c|}{$\begin{array}{l}\text { Organization of } \\
\text { Instruction }\end{array}$} & \multicolumn{2}{|c|}{$\begin{array}{l}\text { Assessment of Students' } \\
\text { Learning }\end{array}$} & \multicolumn{2}{|c|}{ Adjustment of Learning } \\
\hline & Discipline & Rules & Strategy & Method & Portfolio & $\begin{array}{l}\text { Performance } \\
\text { Task }\end{array}$ & Technology & Research \\
\hline $\begin{array}{l}\text { Strategic } \\
\text { Planning }\end{array}$ & $.46^{* *}$ & $.61 * *$ & $.37 * *$ & $.47 * *$ & $.54 * *$ & $.43 * *$ & $.37 * *$ & $.31 * *$ \\
\hline $\begin{array}{l}\text { Problem } \\
\text { Solving }\end{array}$ & $.50 * *$ & $.67 * *$ & $.41 * *$ & $.50 * *$ & $.56 * *$ & $.44 * *$ & $.451 * *$ & $.39 * *$ \\
\hline Change & & & & & & & & \\
\hline Management & $.53 * *$ & $.66 * *$ & $.48 * *$ & $.66 * *$ & $.55 * *$ & $.47 * *$ & $.525 * *$ & $.46 * *$ \\
\hline
\end{tabular}

Shown in table 4 is the correlation between managerial conceptual skills and teaching effectiveness. There is a positive substantial marked relation between the managerial conceptual skills indicators and the teaching effectiveness indicators as evidenced by $\mathrm{r}$ scores between 0.31 and 0.67 . The positive relationship dictates that as the managerial conceptual skills improve the teaching effectiveness also improves. The substantial marked relation is 
between the problem solving and rules (0.67) whereas the lowest correlation is between strategic planning and research (0.31).

The results imply a degree of influence on the teaching effectiveness. Some indicators may have low influence on the teaching effectiveness. However, it should not be taken for granted in order to improve the classroom teaching. There are various activities and initiatives that require the implementation of these indicators. For instance, research is highly necessary for planning and problem solving but maybe not for discipline and rules. These indicators are applied on a case by case basis.

\section{Table 5}

Correlation between the Managerial Human Skills and Teaching Effectiveness

\begin{tabular}{|c|c|c|c|c|c|c|c|c|}
\hline \multirow{2}{*}{ Human } & \multicolumn{2}{|c|}{$\begin{array}{c}\text { Management of Students' } \\
\text { Behavior } \\
\end{array}$} & \multicolumn{2}{|c|}{$\begin{array}{l}\text { Organization of } \\
\text { Instruction }\end{array}$} & \multicolumn{2}{|c|}{$\begin{array}{c}\text { Assessment of Students' } \\
\text { Learning }\end{array}$} & \multicolumn{2}{|c|}{$\begin{array}{l}\text { Adjustment of } \\
\text { Learning }\end{array}$} \\
\hline & Discipline & Rules & Strategy & Method & Portfolio & $\begin{array}{c}\text { Performance } \\
\text { Task }\end{array}$ & Technology & Research \\
\hline Communication & $.57 * *$ & $.58 * *$ & $.53 * *$ & $.53 * *$ & $.62 * *$ & $.49 * *$ & $.43 * *$ & $.32 * *$ \\
\hline $\begin{array}{c}\text { Team } \\
\text { Building }\end{array}$ & $.53 * *$ & $.70 * *$ & $.53 * *$ & $.54 * *$ & $.63 * *$ & $.56 * *$ & $.50 * *$ & $.47 * *$ \\
\hline
\end{tabular}

The table 5 indicates the correlation between managerial human skills and the teaching effectiveness. The degree of correlation ranges from low (0.32) to substantial marked relations (0.70) which are manifested by communication and research (low) and team building and rules (substantial). The positive relationship implies that any improvements in the managerial human skills indicators influence the teaching effectiveness indicators to improve.

It is indeed necessary that teachers develop the managerial human skills as they face children and motivate them to learn. For instance, the language of teachers in the implementation of rules signals a different tempo on how learners act. The same holds true in dealing with their peers in the workplace. In this case, effectiveness suggests a balance of the human skills to enhance relationship with the different key players in the teaching and learning process.

\section{Conclusion}


This study determined the relationship between the managerial skills and teaching effectiveness of the public elementary classroom teachers in Candelaria West District during the School Year 2018-2019. It utilized complete sampling technique of the 162 classroom teachers. The main data gathering tool was a survey questionnaire in checklist form validated by the experts in the field of education. Weighted mean, standard deviation and Pearson Product Moment Correlation were used to analyze the data.

Results showed that the technical, conceptual and human managerial skills of elementary teachers are practiced while the level of teaching effectiveness is always effective in the management of students' behavior and assessment of students' learning and effective in organization of instruction and adjustment of learning. It was further revealed that there was significant relationship in the managerial skills and teaching effectiveness. Therefore, the hypothesis was rejected. This study concludes that there is positive relationship between the managerial skills and the teaching effectiveness of the elementary school teachers.

There is perceived necessity to develop the managerial skills of the teachers. Administrator may provide programs and activities for improvement and application of teachers' managerial skills. The results of the study may also be used as framework for effective teaching training programs. It will also be a great support for teachers to develop learners in reaching the improvement in their accomplishments. It is recommended that next researcher may conduct further study using the framework for effectiveness of classroom teachers to attain success in learning.

\section{Appendices}

\section{Appendix A}

Managerial Technical Skills

\begin{tabular}{|c|c|c|c|}
\hline Technical Skills Indicators & $\mathbf{M}$ & SD & V.I. \\
\hline \multicolumn{4}{|l|}{ Task Management } \\
\hline 1. use various tools and methods to accomplish specific task. & 3.46 & 0.52 & $\mathrm{P}$ \\
\hline 2. give task for student to develop responsibility. & 3.56 & 0.51 & AP \\
\hline 3. successfully completes the goal of school club. & 3.28 & 0.56 & $\mathrm{P}$ \\
\hline 4. organize and control the school event. & 3.26 & 0.53 & $\mathrm{P}$ \\
\hline 5. orient the students to a particular purpose of the project. & 3.49 & 0.57 & $\mathrm{P}$ \\
\hline Over All & 3.41 & 0.45 & $\mathbf{P}$ \\
\hline \multicolumn{4}{|c|}{ Project Implementation } \\
\hline 1. keep the program on track. & 3.45 & 0.55 & $\mathrm{P}$ \\
\hline 2. plan to complete a project on time. & 3.44 & 0.54 & $\mathrm{P}$ \\
\hline 3. establish the clear project scope. & 3.41 & 0.55 & $\mathrm{P}$ \\
\hline 4. take responsibility to the delegation of the task. & 3.39 & 0.52 & $\mathrm{P}$ \\
\hline 5. initiate to work to wider group to be representative of the interest. & 3.4 & 0.56 & $\mathrm{P}$ \\
\hline Over All & 3.42 & 0.55 & $\mathbf{P}$ \\
\hline
\end{tabular}


1. demonstrate the use of technology in many aspect.

ICT

2. update my necessary skills with use of technology.

3. integrate the use of technology in grade level projects.

4. defuse the anxiety and the resistance to technology use.

5. innovate and support technology resources.

$\begin{array}{lll}3.44 & 0.59 & \mathrm{P} \\ 3.43 & 0.59 & \mathrm{P} \\ 3.41 & 0.56 & \mathrm{P} \\ 3.21 & 0.63 & \mathrm{P} \\ 3.43 & 0.54 & \mathrm{P}\end{array}$

\begin{tabular}{|c|c|c|c|}
\hline Conceptual Skills & $\mathbf{M}$ & SD & V.I \\
\hline \multicolumn{4}{|l|}{ Strategic Planning } \\
\hline 1. support the school's mission, vision and values. & 3.74 & 0.45 & AP \\
\hline 2. propose school event and program & 3.48 & 0.55 & $\mathrm{P}$ \\
\hline 3. set the specific objectives and outcomes of the school activities. & 3.49 & 0.56 & $\mathrm{P}$ \\
\hline 4. detail contemporary education trends and expectations in the meeting. & 3.38 & 0.56 & $\mathrm{P}$ \\
\hline 5. understand how learning best occurs as a role of teachers as facilitator. & 3.56 & 0.51 & $\mathrm{AP}$ \\
\hline Over All & 3.53 & $\mathbf{0 . 5 3}$ & $\mathbf{P}$ \\
\hline \multicolumn{4}{|l|}{ Problem Solving } \\
\hline 1. empower to see what goes on in working environment. & 3.49 & 0.54 & $\mathrm{P}$ \\
\hline 2. reflect to appropriate and react to solutions as they arise. & 3.48 & 0.51 & $\mathrm{P}$ \\
\hline 3. devise creative solutions to abstract problems. & 3.35 & 0.56 & $\mathrm{P}$ \\
\hline 4. consider how the members of the club work together. & 3.36 & 0.52 & $\mathrm{P}$ \\
\hline 5. organize teamwork to solve a problem. & 3.45 & 0.56 & $\mathrm{P}$ \\
\hline Over All & $\mathbf{3 . 4 3}$ & 0.54 & $\mathbf{P}$ \\
\hline \multicolumn{4}{|l|}{ Change Management } \\
\hline 1. help to design approach to transitioning individuals of the teacher organization. & 3.4 & 0.56 & $\mathrm{P}$ \\
\hline 2. assist strategy to meet the goal of the organization & 3.4 & 0.56 & $\mathrm{P}$ \\
\hline 3. evaluate the current status to reach the desired aim. & 3.4 & 0.56 & $P$ \\
\hline
\end{tabular}

Over All

\section{Appendix B \\ Managerial Conceptual Skills}


4. improve the existing aim of the school officers.

$\begin{array}{lll}3.4 & 0.55 \quad \mathrm{P}\end{array}$

5. adapt to changes in their current environment.

$3.44 \quad 0.55 \quad \mathrm{P}$

Over All

$3.41 \quad 0.56 \quad P$

\begin{tabular}{|c|c|c|c|}
\hline Human Skills & $\mathbf{M}$ & SD & V.I. \\
\hline \multicolumn{4}{|l|}{ Communication } \\
\hline 1. advocate of good role model for clear and consistent communication. & 3.52 & 0.51 & AP \\
\hline 2. match words to actions. & 3.54 & 0.5 & AP \\
\hline $\begin{array}{l}\text { 3. develop integrity as a leader, being committed to open the line of } \\
\text { communication. }\end{array}$ & 3.53 & 0.51 & AP \\
\hline 4. communicate bad news as effectively as good news. & 3.29 & 0.64 & $\mathrm{P}$ \\
\hline $\begin{array}{l}\text { 5. search for new strategies of communicating with their external and } \\
\text { internal publics. }\end{array}$ & 3.4 & 0.61 & $\mathrm{P}$ \\
\hline Over All & 3.45 & 0.56 & $\mathbf{P}$ \\
\hline \multicolumn{4}{|l|}{ Team building } \\
\hline 1. step up leadership roles to achieve goals. & 3.39 & 0.58 & $\mathrm{P}$ \\
\hline 2. share expertise with the rest of the school team. & 3.44 & 0.53 & $\mathrm{P}$ \\
\hline 3. lead without being formal leaders. & 3.33 & 0.62 & $\mathrm{P}$ \\
\hline 4. share the roles among team members. & 3.43 & 0.54 & $\mathrm{P}$ \\
\hline 5. advocate that all teachers play a role. & 3.53 & 0.52 & AP \\
\hline Over All & 3.42 & 0.56 & $\mathbf{P}$ \\
\hline
\end{tabular}

\section{Appendix D}

Teaching Effectiveness in Management of Students' Behavior

\begin{tabular}{|c|c|c|c|}
\hline Management of Students' Behavior & $\mathbf{M}$ & SD & V.I. \\
\hline \multicolumn{4}{|l|}{ Discipline } \\
\hline 1. bring the students in the harmony with the ideas. & 3.59 & 0.53 & $\mathrm{AE}$ \\
\hline 2. set principles in the learning environment. & 3.59 & 0.54 & $\mathrm{AE}$ \\
\hline 3. seek to eliminate issues in the classroom. & 3.6 & 0.53 & $\mathrm{AE}$ \\
\hline 4. solve the problems of students. & 3.64 & 0.54 & $\mathrm{AE}$ \\
\hline 5. spend time in addressing discipline to the development of pupils' & & & \\
\hline attitude. & 3.61 & 0.51 & $\mathrm{AE}$ \\
\hline Over All & 3.6 & $\mathbf{0 . 5 3}$ & $\mathbf{A E}$ \\
\hline \multicolumn{4}{|l|}{ Rules } \\
\hline 1. initiate to follow school rules. & 3.65 & 0.5 & $\mathrm{AE}$ \\
\hline 2. clear the expectations of appropriate student behavior. & 3.59 & 0.52 & $\mathrm{AE}$ \\
\hline 3. post rules before the first day of school. & 3.63 & 0.53 & $\mathrm{AE}$ \\
\hline 4. communicate to the students and parents verbally and in written & 363 & 0.5 & $\mathrm{AE}$ \\
\hline 5. write in form about expected and appropriate behavior. & 3.48 & 0.58 & $\mathrm{E}$ \\
\hline Over All & 3.59 & $\mathbf{0 . 5 3}$ & $\mathbf{A E}$ \\
\hline
\end{tabular}




\section{Appendix E}

\section{Teaching Effectiveness in Organization of Instruction}

\begin{tabular}{|c|c|c|c|}
\hline Organization of Instruction & $\mathbf{M}$ & SD & V.I. \\
\hline \multicolumn{4}{|l|}{ Strategy } \\
\hline 1. develop the range of student' abilities and aptitudes. & 3.59 & 0.51 & $\mathrm{AE}$ \\
\hline 2. provide opportunities for the different needs of the students. & 3.54 & 0.51 & $\mathrm{AE}$ \\
\hline 3. use techniques that engage and challenge the pupils to achieve their & 355 & 05 & $\mathrm{AF}$ \\
\hline 4. present new materials that enables the pupils to connect them to & & & \\
\hline what they knew. & 3.51 & 0.51 & $\mathrm{AE}$ \\
\hline 5. provide engaging and motivating activities & 3.49 & 0.53 & $\mathrm{E}$ \\
\hline Over All & 3.6 & $\mathbf{0 . 5 3}$ & $\mathbf{A E}$ \\
\hline \multicolumn{4}{|l|}{ Methods } \\
\hline 1. incorporate different sources in using a variety of methods. & 3.49 & 0.57 & $\mathrm{E}$ \\
\hline 2. integrate the learning objectives in the curriculum. & 3.51 & 0.53 & $\mathrm{AE}$ \\
\hline 3. adapt instruction to meet students' needs. & 3.54 & 0.51 & $\mathrm{AE}$ \\
\hline 4. innovate materials for students' active interactions. & 3.49 & 0.55 & $\mathrm{E}$ \\
\hline 5. look for new methods to promote student's level of understanding & 3.49 & 0.55 & $\mathrm{E}$ \\
\hline Over All & 3.5 & 0.54 & $\mathbf{E}$ \\
\hline
\end{tabular}

\section{Appendix F}

Teaching Effectiveness in Assessment of Students' Learning

\begin{tabular}{lccc}
\hline \multicolumn{1}{c}{ Assessment of Students' Learning } & M & SD & V.I. \\
\hline Portfolio & & & \\
1. collect various pieces of students work. & 3.59 & 0.53 & AE \\
2. look for students' works that exemplify the criteria. & 3.59 & 0.51 & $\mathrm{AE}$ \\
3. state the procedures for evaluating student work. & 3.56 & 0.51 & $\mathrm{AE}$ \\
4. allow the think the students about each item in their portfolio. & 3.51 & 0.54 & $\mathrm{AE}$ \\
5. make the students have the opportunity to evaluate their own work. & 3.56 & 0.52 & $\mathrm{AE}$ \\
& $\mathbf{3 . 5 6}$ & $\mathbf{0 . 5 2}$ & $\mathbf{A E}$ \\
\hline
\end{tabular}

\section{Performance Task}

1. engage students to perform situations that are meaningful, and ageappropriate.

2. give students opportunity to express and assess their ideas.

$3.57 \quad 0.51 \quad \mathrm{AE}$

$3.62 \quad 0.5 \quad \mathrm{AE}$

3. state the standards in assessing student's performance.

$3.52 \quad 0.56 \quad \mathrm{AE}$

4. rate the students work with their collaborative effort.

$3.57 \quad 0.51 \quad \mathrm{AE}$

5. generate feedback to make the student's aware of their strengths and weaknesses.

Over All
$3.51 \quad 0.54 \quad \mathrm{AE}$

$3.56 \quad 0.52 \quad$ AE




\section{Appendix G}

\section{Teaching Effectiveness in Adjustment of Learning}

\begin{tabular}{|c|c|c|c|}
\hline Adjustment of Learning & $\mathbf{M}$ & SD & V.I. \\
\hline \multicolumn{4}{|l|}{ Technology } \\
\hline 1. utilize learning technologies in teaching. & 3.56 & 0.55 & $\mathrm{AE}$ \\
\hline $\begin{array}{l}\text { 2. introduce different aspects of innovation in the teaching and learning } \\
\text { process. }\end{array}$ & 3.52 & 0.54 & $\mathrm{AE}$ \\
\hline 3. have a vision of how education systems run if ICT is integrated into & & & \\
\hline teaching and learning process. & 3.46 & 0.57 & $\mathrm{AE}$ \\
\hline 4. give chance to students to use ICT resources. & 3.35 & 0.67 & $\mathrm{AE}$ \\
\hline 5. reduce the digital gap. & 3.36 & 0.58 & $\mathrm{AE}$ \\
\hline Over All & 3.45 & 0.58 & $\mathbf{A E}$ \\
\hline \multicolumn{4}{|l|}{ Research } \\
\hline $\begin{array}{l}\text { 1. introduce different aspects of upgrading in the teaching and learning } \\
\text { process. }\end{array}$ & 3.5 & 0.53 & $\mathrm{AE}$ \\
\hline 2. address advancement for students achievement. & 3.42 & 0.51 & $\mathrm{E}$ \\
\hline 3. engage in research and modernization. & 3.3 & 0.61 & $\mathrm{E}$ \\
\hline 4. view a path towards better student achievement. & 3.46 & 0.55 & $\mathrm{E}$ \\
\hline $\begin{array}{l}\text { 5. initiate to promote better classroom practices in the aspects of } \\
\text { pedagogy and parental involvement. }\end{array}$ & 3.51 & 0.54 & $\mathrm{AE}$ \\
\hline Over All & 3.44 & 0.55 & $\mathbf{E}$ \\
\hline
\end{tabular}

\section{References}

Abila, J. G. (2014) Management Practices and Teachers: Performance Satisfaction Among Teachers in Fule Almeda District: Input to Quality Management. (Unpublished Thesis). Laguna State Polytechnic University. San Pablo City.

Agbatogun, A. O. (2012). Investigating Nigerian primary school teachers' preparedness to adopt personal response system in ESL classroom. International Journal of Elementary Education. International Electronic Journal of Elementary Education, 4(2), 377-394.

Arnseth, H.C., \& Hatlevik, O.E. (2010). Challenges in aligning pedagogical practices and pupils' competencies with the Information Society's demands: The case of Norway. Issues and challenges. (Thesis). Hershey. IGI global.

Barberos, T., Gonzalo, A., Payadogdog, A. The Effect of Teachers' Teaching Style on Students' Motivation. Retrieved from January 2019 from https://steinhardt.nyu.edu/teachlearn/research/action/motivation

Bell, L., Bush, T., Middlewood, D. (2011). Principles of educational leadership management. (2nd Ed.). Sage Publication 
Buabeng and Mbati, M. G. (2014). Factors Influencing School Principals' Integration of ICT in Administration of Public Secondary Schools in Githunguri Sub Country. Kiambu. (Thesis). Kenya :University of Nairobi.

Carpo, R. E. (2014). Building Mathematics Confidence: Determining the Strategies utized by intermediate Teachers of Selected Public School in Lucena City. (Unpublished Thesis) Manuel S. Enverga University Foundation Candelaria Inc. Candelaria, Quezon.

Doyle A. (2016). Conceptual Skills List and Examples Conceptual Skills and Keywords for Resumes, Cover Letters, and Interviews. Retrieved March 2018 from https://www.thebalance.com/conceptual-skills-list-and-examples-4142004

Durrant, J. (2010). Positive Discipline in Everyday Teaching. Save the Children. Bangkok.

Glorioso, L. (2016). Functions and Management Strategies of School Principals: Impact on the Job Satisfaction and Self-Efficacy of Public Elementary School Teachers. (Unpublished Thesis). Laguna State Polytechnic University. San Pablo City

Gumz, M. (2017). 5 best practices for Project Implementation. Retrieved February 2018 from https://teamweek.com/blog/2017/04/5-best-practices-successful-projectimplementation/

Javier, N.T. (2016). School Head's Management Skills and Work Values towards Efficiency and Effectiveness of the Public Secondary Schools. (Unpublished Thesis). Laguna State Polytechnic University.

Juan, M. A. T., \& Laseten, R. C. S. (2016). Relationship between Teacher Education Students' Oral Communication Apprehensions in English and Their Academic Performance. International Journal of Languages, Literature and Linguistics, 2 (2).

Khandaghi, M.A., \& Farasat, M. (2011). The Effect of Teacher's Teaching Style on Students' Adjustment. (Thesis). Iran. Ferdowsi University of Mashhad.

Laylo, M. C. (2018). School Culture and Climate:Inputs to Schools'Best Practices and Improved School Performance.(Dissertation). Laguna State Polytechnic University. San Pablo City.

Libit, I. D. (2016). Management Styles and Academic Strategies of Performing Teachers in Public Secondary Schools in Cluster V Division of Quezon: Basis in Designing Framework for Effective Teaching. (Unpublished Thesis). Laguna State Polytechnic University. San Pablo City.

Locke, E. (2010). Principles of Organizational Behavior: Indispensable Knowledge for Evidence-Based Management. (Thesis). New York: Wilev.

Lucas, R. I. G. (2017). A study on Portfolio Assessment as Effective Student Self- Evaluation Scheme. Retrieved February 2019 from https://www.brookings.edu/wpcontent/uploads/2017/03/global-20170307-philippines-case-study.pdf.

Magbojos, C. R. (2012). Managerial Skills Development of Selected Private Institutions of Higher Learning in Batangas. (Thesis). Batangas, Philippines. 
Maughan S., Teeman D., Wilson, R. What Leads to Positive Change in Teaching Practice. (Research). National Foundation for Educational Research, The Mere, Upton Park, Slough, Berkshire SL1.

Morales, M.P.E. (2016). Examining teachers' conception of and needs on action research. (Thesis). Manila. Philippine Normal University.

O'Neill, S. (2009). An Initiative of the Director General's Classroom First Strategy. Retrieved February 2018 fromhttps://www.education.wa.edu.au/documents/43634987/44524721/Classroom+Fi rst+Strategy.pdf/61e279ac-d613-5983-440c-f3f41b40ec04

Patrinos, H. A. (2010). Decentralized Decision Making in Schools: The Theory and Evidence on School-Based Management. (Thesis) Washington, DC: World Bank Publications.

Ranade, R. (2009). Effectiveness of Team-Building and Teamwork in Real and Virtual World. (Thesis). Clemson. University.

Refugido, K. M L. (2015). Comparative Study of Teaching Streategies between Private and Public Schhols Teachers of Grade 9 Student of Selected High Schools in Tiaong Quezon. (Unpublished Thesis). Manuel S. Enverga University Foundation Candelaria Inc. Candelaria, Quezon.

Robbins, S. and Coulter, M. (2009). Management. Pearson prentice hall. New York. Lawrence Erlbaum Associates.

Ryan K., Cooper J. M., Tauer, S. (2013). Teaching for Student Learning: Becoming A Master Teacher. USA. Wadsworth, Cengage Learning.

Salandanan, G. G. (2012). Elements of Teaching. Metro Manila. Lorimar Publishing Inc.

Scaggs S. J. A. (2009). The Effects of School Discipline on Students'Social Bonds. (Thesis) Kansas, City. Missouri University.

Stecher, B. (2010). Performance assessment in an era of standards-based educational accountability. (Thesis). Stanford, CA. Stanford University, Stanford Center for Opportunity Policy in Education.

Vishwanath, B. (2012). Role of a teacher in 21st century. The criterion. An International journal in English, 3.

Visiliko, K. (2015). The Interpersonal Relations between Teachers and Principal: Factors in the All Around Development of Student's Personality. (Thesis). Humanities and Social Sciences Review, Greece.

Vu, P. A. (2009). The Influence of Classroom Characteristics and Student Relations on Student Academic Achievement. Retrieved April 2018 fromhttps://pdfs.semanticscholar.org/f06a/b3a2e61853d31a6b81fae67b386d21f8ec03 .pdf.

William, D., \& Thompson, M. (2008). Integrating assessment with learning: What will it take to make it work? The future of assessment: Shaping teaching and learning. New York. Lawrence Erlbaum Associates. 